\title{
The Analysis of Hypothesis Testing on Popularities of Rare Sugars
}

\author{
Hiromasa Takeyasu $^{1}$, Yuki Higuchi ${ }^{2}$, Yoshiko Saitoh $^{1} \&$ Kazuhiro Takeyasu ${ }^{3}$ \\ ${ }^{1}$ Kagawa Junior College, Japan \\ ${ }^{2}$ Setsunan University, Japan \\ ${ }^{3}$ Tokoha University, Japan \\ Correspondence: Kazuhiro Takeyasu, College of Business Administration, Tokoha University, Shizuoka 417-0801 \\ Japan. Tel: 81-545-372-036.
}

Received: October 22, 2017

Accepted: November 4, 2017

Online Published: November 13, 2017

doi:10.5430/ijba.v8n7p33

URL: https://doi.org/10.5430/ijba.v8n7p33

\begin{abstract}
The Rare Sugars exist naturally and have many kinds (more than 50). They have good effect for health such as prevention of increasing the blood-sugar level after eating, suppression of fat accumulation, suppression of increasing the blood pressure, and anti-oxidative effect etc. It is in the spotlight for many people especially for those who are in the metabolic syndrome. The Rare Sugars are prevailing now in Japan. It is utilized in cooking, drinks and cakes etc. The big food companies are putting it into their products and make promotions by TV and other media. There are few related papers concerning the marketing research and its utilization of this matter. In this paper, a questionnaire investigation is executed to the student of Kagawa Junior College in order to clarify consumers' current condition and their consciousness, and to seek the possibility of utilizing the Rare Sugars. Fundamental statistical analysis and Hypothesis Testing analysis are performed based on that. Some interesting and instructive results were obtained.
\end{abstract}

Keywords: rare sugars, health, consumer, hypothesis testing

\section{Introduction}

The Rare Sugars' study has launched on $1980^{\text {th }}$ by Professor Takeshi Izumori (Kagawa University). The way to the mass production was developed by the method of enzymatic reaction. The International Society of Rare Sugars was established in 2001. Local government of Kagawa Prefecture comes to assist this research activity on this big innovation newly born in Kagawa Prefecture. The Rare Sugars have advantage that a blood-sugar level does not increase so much after eating, in spite of it being a sugar. And it also holds the upturn of the blood pressure. Therefore it is expected as a new functional material for the prevention of metabolic syndrome.

By the way, one kind of the Rare Sugar D-psicose has the following characteristics.

(1) a sweetening made by the natural starch

(2) non-calorie and its sweetness is $70 \%$ to those of sugar

(3) organoleptic property of coolness and sharpness in taste

Many medical research papers are published on the Rare Sugars as follows.

Analysis of the function of D-psicose; Hossain et al., 2011, Hayashi et al., 2010, Iida et al., 2010

Analysis of the function of D-allose; Yamada et al., 2012, Kajikawa et al., 2010, Hirata et al., 2009

On the other hand, these are few papers analyzed by the viewpoint from consumers. The Rare Sugars is good for the health and is sold in the market as a sweetening, seasoning or functional ingredient for food. The Rare Sugars are prevailing now in Japan. It is utilized in cooking, drinks and cakes etc. The big food companies are putting it into their products and make promotions by TV and other media.

In this paper, a questionnaire investigation is executed to the student of Kagawa Junior College in order to clarify the recognition level among consumers and to pursue the future possibility of the Rare Sugars. Basic statistical analysis and Hypothesis Testing analysis are conducted. The nine issues are set and Hypothesis Testing analysis is executed.

The rest of this paper is organized as follows. In section 2, outline of the questionnaire investigation and its basic statistical results are exhibited. After that, Hypothesis Testing analysis is performed in section 3, which is followed 
by the remarks of section 4 .

\section{Outline and the Basic Statistical Results of the Questionnaire Research}

\subsection{Outline of the Questionnaire Research}

A questionnaire investigation is executed to the student of Kagawa Junior College in order to clarify the recognition level among consumers and to pursue the future possibility of the Rare Sugars. The outline of the questionnaire research is as follows. The questionnaire sheet is attached in Appendix.
(1) Scope of investigation
: Student of Kagawa Junior College
(2) Period
: (1) April - June 2015, (2) April - June 2017
(3) Method
: Leave until called for
(4) Collection
: $\quad$ Number of distribution (1) 186, (2) 335
Number of collection (1)186 (collection rate 100.0\%), (2) 335 (collection rate $100.0 \%$ )
Valid answer (1)186, (2) 333

\subsection{Basic Statistical Results}

Now, we show the main summary results by single variable.

(1) Basic characteristics of answerers

\begin{tabular}{lrr} 
Q32 Sex & & \\
\hline & Frequency & $\%$ \\
\hline Male & 30 & 9.0 \\
Female & 303 & 91.0 \\
\hline Total & 333 & 100.0 \\
\hline
\end{tabular}

Q33 Age

\begin{tabular}{lrr}
\hline & Frequency & $\%$ \\
\hline-19 & 272 & 81.7 \\
$20-29$ & 52 & 15.6 \\
$30-39$ & 3 & 0.9 \\
$40-49$ & 4 & 1.2 \\
$50-59$ & 1 & 0.3 \\
$60-$ & 1 & 0.3 \\
\hline Total & 333 & 100.0 \\
\hline
\end{tabular}

Q34 Occupation

\begin{tabular}{lrr}
\hline & Frequency & $\%$ \\
\hline Student & 324 & 97.9 \\
Company Employee & 3 & 0.9 \\
Clerk of Organization & 1 & 0.3 \\
Housewife & 1 & 0.3 \\
Miscellaneous & 2 & 0.6 \\
\hline Total & 331 & 100.0 \\
\hline
\end{tabular}


(2) Summary results for the items used in Hypothesis Testing

Q12 I want to know where I can buy it because I want to use it as a seasoning.

\begin{tabular}{|c|c|c|c|c|c|c|}
\hline & $\begin{array}{c}\text { Think it } \\
\text { very much }\end{array}$ & $\begin{array}{l}\text { Slightly } \\
\text { think so }\end{array}$ & $\begin{array}{c}\text { Cannot say } \\
\text { either }\end{array}$ & $\begin{array}{c}\text { Slightly do } \\
\text { not think so }\end{array}$ & $\begin{array}{l}\text { Do not } \\
\text { think so }\end{array}$ & Total \\
\hline Frequency & 54 & 111 & 108 & 45 & 13 & 331 \\
\hline$\%$ & 16.3 & 33.5 & 32.6 & 13.6 & 3.9 & 100.0 \\
\hline \multicolumn{7}{|c|}{ Q13 I want to know where I can get information because I want to use it as a supplemer } \\
\hline Frequency & 104 & 112 & 83 & 23 & 9 & 331 \\
\hline$\%$ & 31.4 & 33.8 & 25.1 & 6.9 & 2.7 & 100.0 \\
\hline \multicolumn{7}{|c|}{ Q14 I want to know the hospital where the Rare Sugar is used as a tool for treatment. } \\
\hline Frequency & 57 & 115 & 110 & 36 & 14 & 332 \\
\hline$\%$ & 17.2 & 34.6 & 33.1 & 10.8 & 4.2 & 100.0 \\
\hline \multicolumn{7}{|c|}{ Q25 Do you take interest in a diet? } \\
\hline Frequency & 128 & 105 & 52 & 23 & 24 & 332 \\
\hline$\%$ & 38.6 & 31.6 & 15.7 & 6.9 & 7.2 & 100.0 \\
\hline \multicolumn{7}{|c|}{ Q26 Are you careful for the health? } \\
\hline Frequency & 44 & 127 & 127 & 23 & 10 & 331 \\
\hline$\%$ & 13.3 & 38.4 & 38.4 & 6.9 & 3.0 & 100.0 \\
\hline \multicolumn{7}{|c|}{ Q27 Do you take interest in the designated health food? } \\
\hline Frequency & 49 & 107 & 124 & 37 & 14 & 331 \\
\hline$\%$ & 14.8 & 32.3 & 37.5 & 11.2 & 4.2 & 100.0 \\
\hline
\end{tabular}

\section{Hypothesis Testing}

Hereinafter we make Hypothesis Testing analysis based upon the questionnaire investigation data.

(1) Setting Hypothesis

In the Hypothesis Testing analysis, nine issues are set as follows.

A-1) Those who want to know where he/she can buy it because he/she wants to use it as a seasoning have interest in a diet.

A-2) Those who want to know where he/she can buy it because he/she wants to use it as a seasoning are careful of his/her health.

A-3) Those who want to know where he/she can buy it because he/she wants to use it as a seasoning have interest in the designated health food.

A-4) Those who want to know where he/she can get information because he/she wants to use it as a supplement have interest in a diet.

A-5) Those who want to know where he/she can get information because he/she wants to use it as a supplement are careful of his/her health.

A-6) Those who want to know where he/she can get information because he/she wants to use it as a supplement have interest in the designated health food.

A-7) Those who want to know the hospital where the Rare Sugar is used as a tool for treatment have interest in a diet.

A-8) Those who want to know the hospital where the Rare Sugar is used as a tool for treatment are careful of his/her health.

A-9) Those who want to know the hospital where the Rare Sugar is used as a tool for treatment have interest in the designated health food.

Now, we set the following nine Null hypotheses.

A-1) There is not so much difference whether those who want to know where he/she can buy it because he/she 
wants to use it as a seasoning have interest in a diet or not.

A-2) There is not so much difference whether those who want to know where he/she can buy it because he/she wants to use it as a seasoning are careful of his/her health or not.

A-3) There is not so much difference whether those who want to know where he/she can buy it because he/she wants to use it as a seasoning have interest in the designated health food or not.

A-4) There is not so much difference whether those who want to know where he/she can get information because he/she wants to use it as a supplement have interest in a diet or not.

A-5) There is not so much difference whether those who cannot guess how he/she should use the Rare Sugar to what kind of cooking are careful of his/her health or not.

A-6) There is not so much difference whether those who want to know where he/she can get information because he/she wants to use it as a supplement have interest in the designated health food or not.

A-7) There is not so much difference whether those who want to know the hospital where the Rare Sugar is used as a tool for treatment have interest in a diet or not.

A-8) There is not so much difference whether those who want to know the hospital where the Rare Sugar is used as a tool for treatment are careful of his/her health or not.

A-9) There is not so much difference whether those who want to know the hospital where the Rare Sugar is used as a tool for treatment have interest in the designated health food or not.

\section{(2) Hypothesis Testing}

The results of Hypothesis Testing analysis are as follows.

Null Hypothesis A-1): There is not so much difference whether those who want to know where he/she can buy it because he/she wants to use it as a seasoning have interest in a diet or not.

Summary table for Null Hypothesis A-1) is exhibited in Table 1.

Table 1. Summary table for Null Hypothesis A-1)

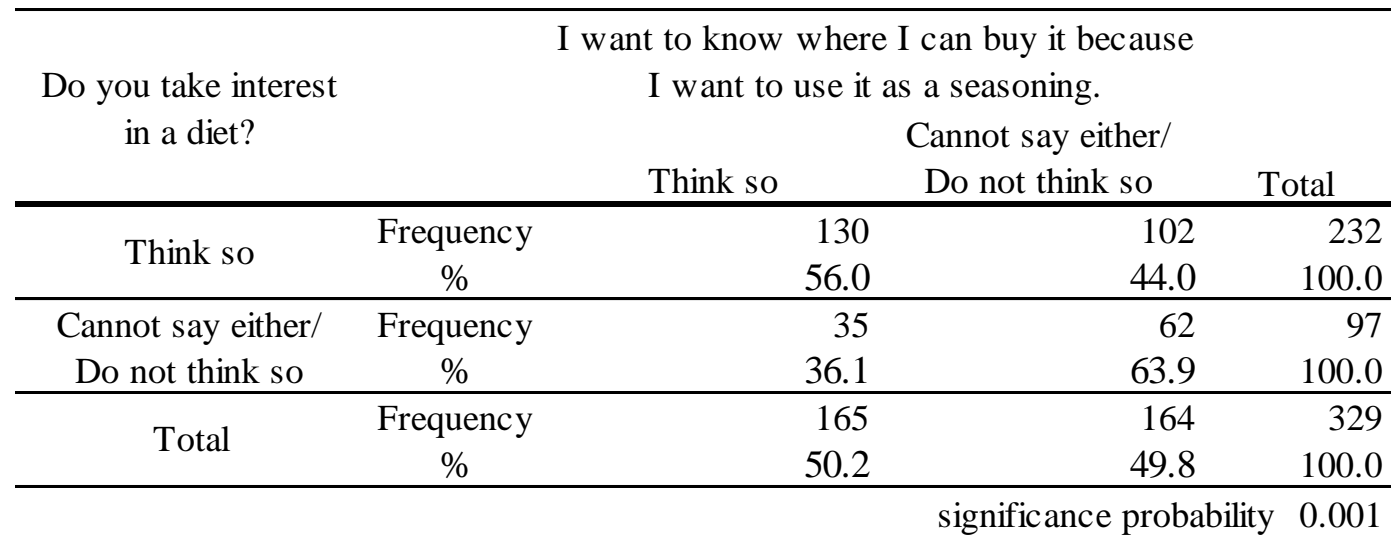




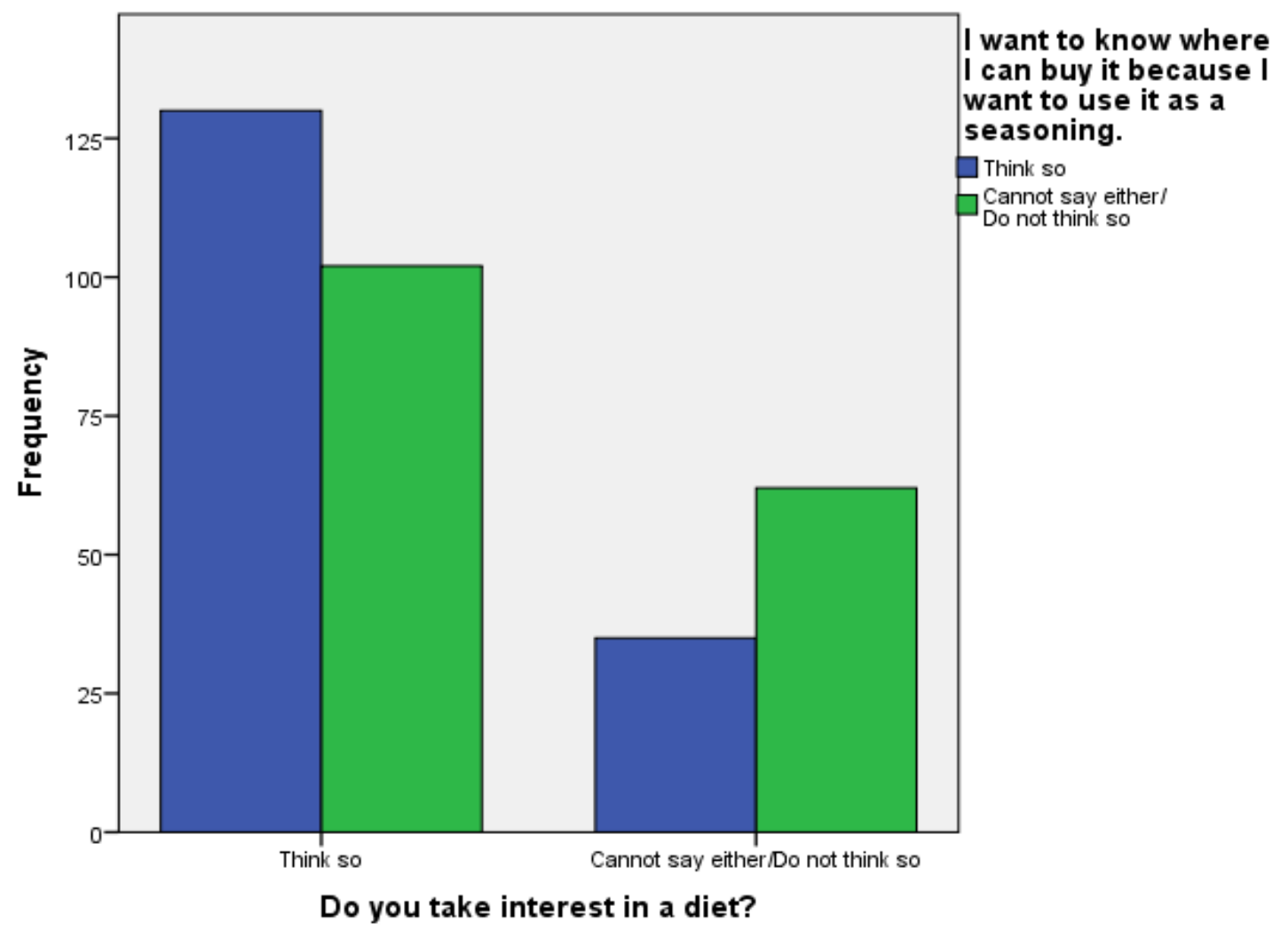

Figure 1. Summary for Null Hypothesis A-1)

The null hypothesis is rejected with $1 \%$ significance level. It can be said that those who want to know where he/she can buy it because he/she wants to use it as a seasoning have interest in a diet.

Null Hypothesis A-2): There is not so much difference whether those who want to use it in the cooking are careful of his/her health or not.

Summary table concerning Null Hypothesis A-2) is exhibited in Table 2.

Table 2. Summary table for Null Hypothesis A-2)

\begin{tabular}{|c|c|c|c|c|}
\hline \multirow[t]{2}{*}{$\begin{array}{l}\text { Are you careful for } \\
\text { the health? }\end{array}$} & \multicolumn{4}{|c|}{$\begin{array}{c}\text { I want to know where I can buy it because } \\
\text { I want to use it as a seasoning. } \\
\text { Cannot say either/ }\end{array}$} \\
\hline & & Think so & Do not think so & Total \\
\hline \multirow{2}{*}{ Think so } & Frequency & 100 & 69 & 169 \\
\hline & $\%$ & 59.2 & 40.8 & 100.0 \\
\hline \multirow{2}{*}{$\begin{array}{c}\text { Cannot say either/ } \\
\text { Do not think so }\end{array}$} & Frequency & 64 & 95 & 159 \\
\hline & $\%$ & 40.3 & 59.7 & 100.0 \\
\hline \multirow{2}{*}{ Total } & Frequency & 164 & 164 & 328 \\
\hline & $\%$ & 50.0 & 50.0 & 100.0 \\
\hline
\end{tabular}




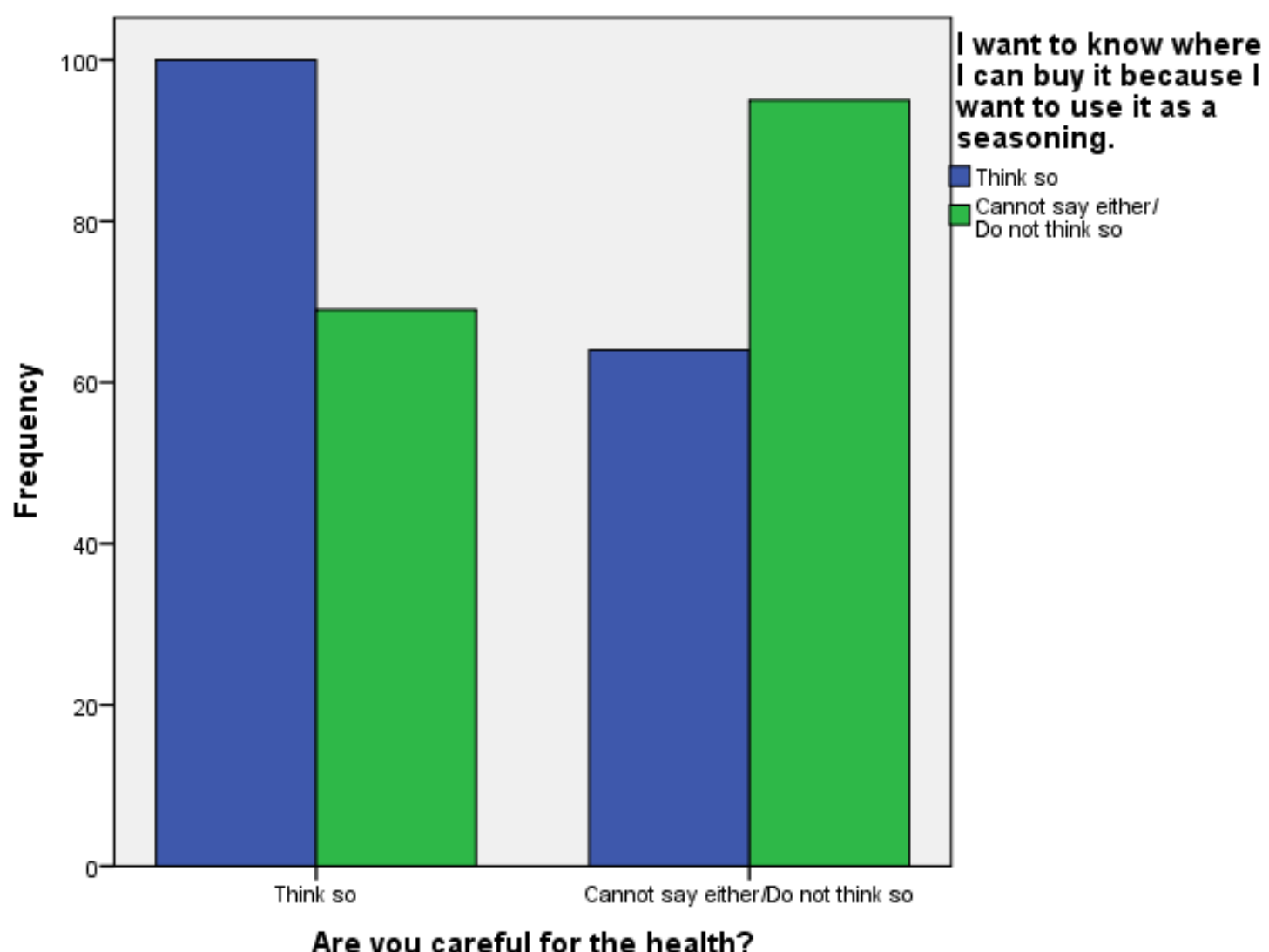

Figure 2. Summary for Null Hypothesis A-2)

The null hypothesis is rejected with $1 \%$ significance level. It can be said that those who want to know where he/she can buy it because he/she wants to use it as a seasoning are careful of his/her health.

Null Hypothesis A-3): There is not so much difference whether those who want to know where he/she can buy it because he/she wants to use it as a seasoning have interest in the designated health food or not.

Summary table concerning Null Hypothesis A-3) is exhibited in Table 3.

Table 3. Summary table for Null Hypothesis A-3)

\begin{tabular}{|c|c|c|c|c|}
\hline \multirow[t]{2}{*}{$\begin{array}{l}\text { Do you take interest in the } \\
\text { designated health food? }\end{array}$} & \multicolumn{4}{|c|}{$\begin{array}{c}\text { I want to know where I can buy it because } \\
\text { I want to use it as a seasoning. } \\
\text { Cannot say either/ }\end{array}$} \\
\hline & & Think so & Do not think so & Total \\
\hline Think $\mathrm{s}$ & Frequency & 86 & 69 & 155 \\
\hline InInk so & $\%$ & 55.5 & 44.5 & 100.0 \\
\hline Cannot say either/ & Frequency & 78 & 95 & 173 \\
\hline Do not think so & $\%$ & 45.1 & 54.9 & 100.0 \\
\hline \multirow{2}{*}{ Total } & Frequency & 164 & 164 & 328 \\
\hline & $\%$ & 50.0 & 50.0 & 100.0 \\
\hline
\end{tabular}




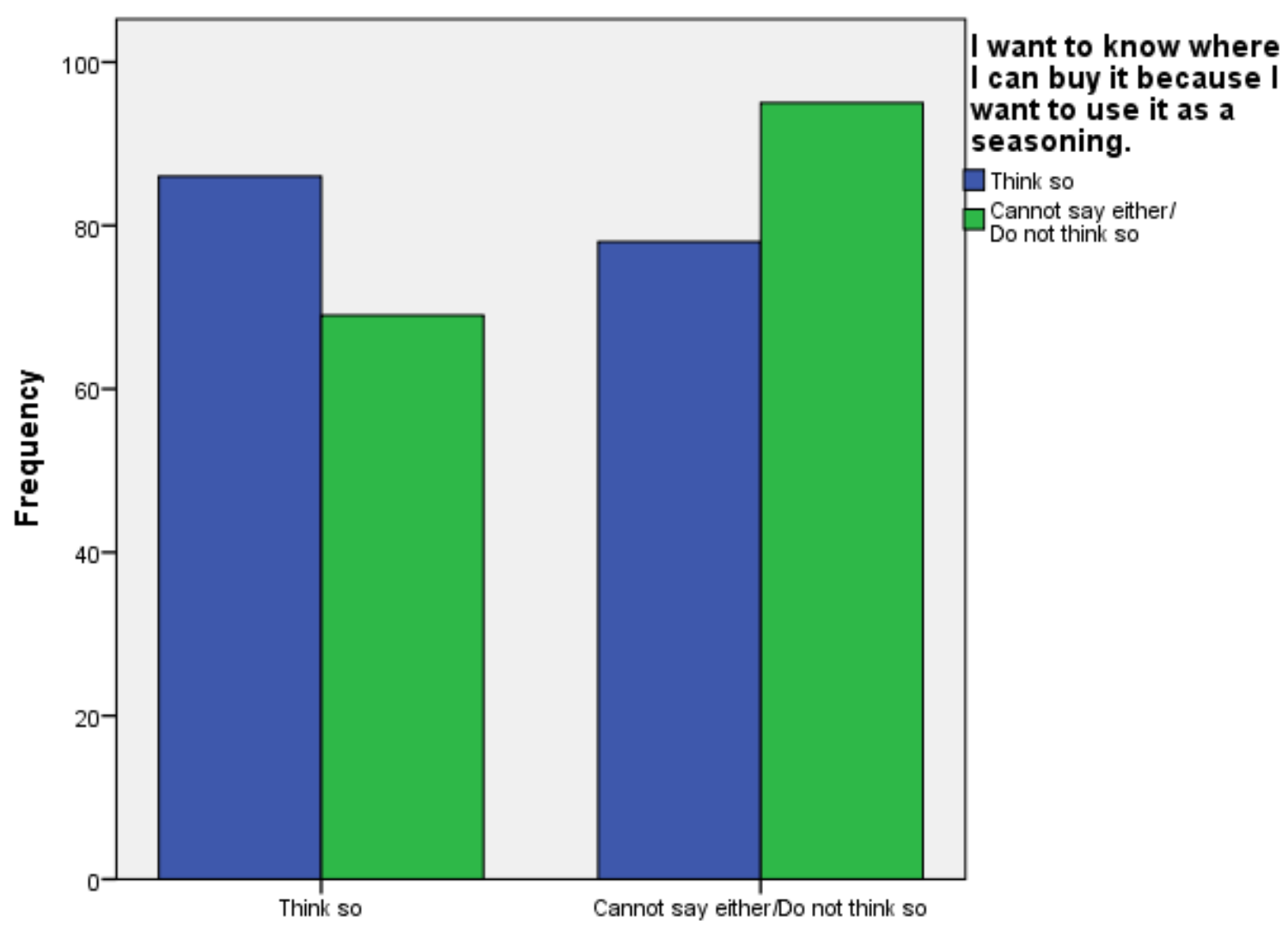

Do you take interest in the designated health food?

Figure 3. Summary for Null Hypothesis A-3)

The null hypothesis is not rejected. It can be said that there is not so much difference whether those who want to know where he/she can buy it because he/she wants to use it as a seasoning have interest in the designated health food or not.

Null Hypothesis A-4): There is not so much difference whether those who want to know where he/she can get information because he/she wants to use it as a supplement have interest in a diet or not.

Summary table concerning Null Hypothesis A-4) is exhibited in Table 4.

Table 4. Summary table for Null Hypothesis A-4)

\begin{tabular}{|c|c|c|c|c|}
\hline \multirow[t]{2}{*}{$\begin{array}{c}\text { Do you take interest } \\
\text { in a diet? }\end{array}$} & & \multicolumn{3}{|c|}{$\begin{array}{l}\text { I want to know where I can get information } \\
\text { because I want to use it as a supplement. } \\
\text { Cannot say either/ }\end{array}$} \\
\hline & & Think so & Do not think so & Total \\
\hline Think so & Frequency & 163 & 69 & 232 \\
\hline & $\%$ & 70.3 & 29.7 & 100.0 \\
\hline Cannot say either/ & Frequency & 52 & 45 & 97 \\
\hline Do not think so & $\%$ & 53.6 & 46.4 & 100.0 \\
\hline Tot & Frequency & 215 & 114 & 329 \\
\hline 10tal & $\%$ & 65.3 & 34.7 & 100.0 \\
\hline
\end{tabular}




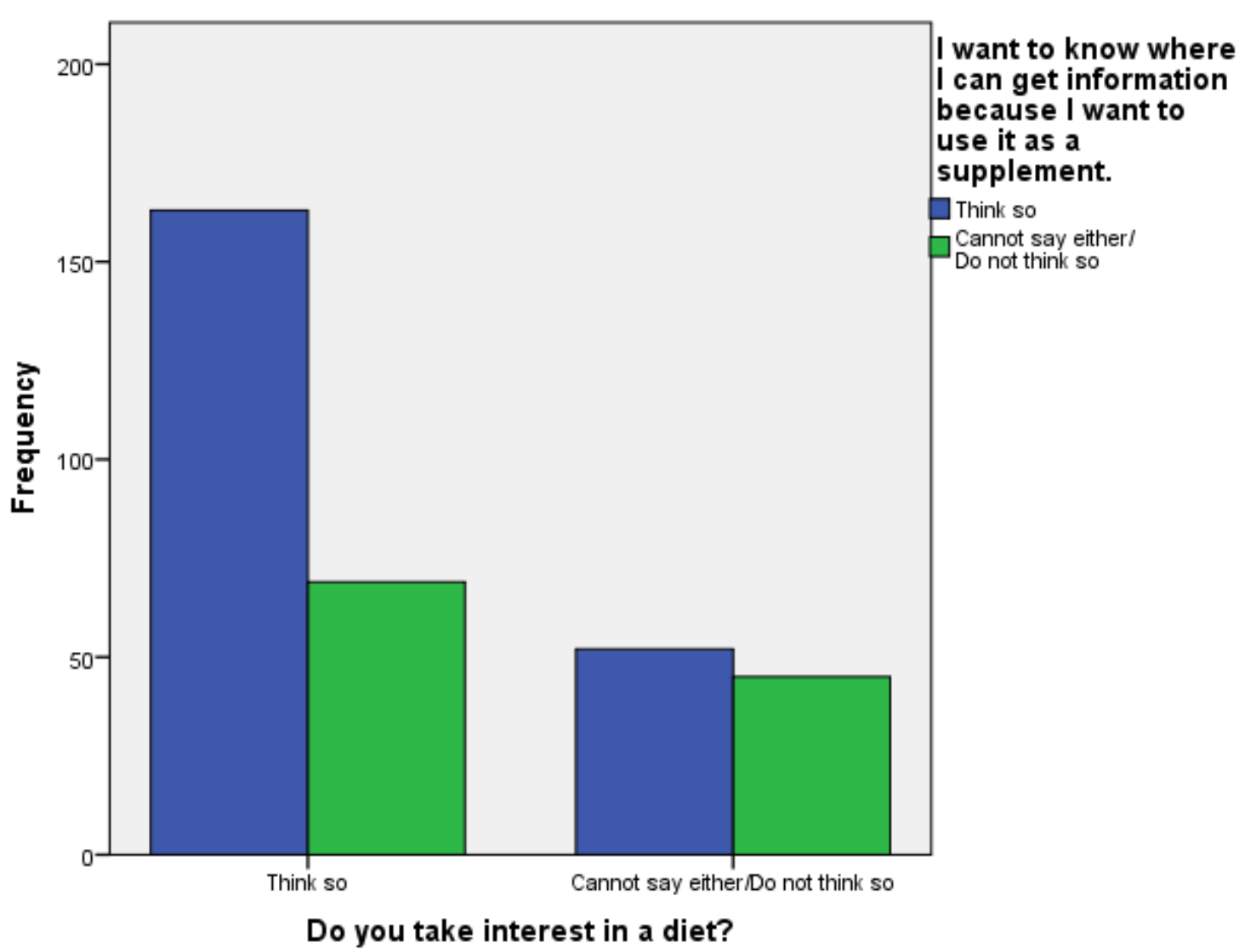

Figure 4. Summary for Null Hypothesis A-4)

The null hypothesis is rejected with $1 \%$ significance level. It can be said that those who want to know where he/she can get information because he/she wants to use it as a supplement have interest in a diet.

Null Hypothesis A-5): There is not so much difference whether those who want to know where he/she can get information because he/she wants to use it as a supplement are careful of his/her health or not.

Summary table concerning Null Hypothesis A-5) is exhibited in Table 5.

Table 5. Summary table for Null Hypothesis A-5)

\begin{tabular}{ccrrr}
\hline $\begin{array}{c}\text { Are you careful for } \\
\text { the health? }\end{array}$ & & $\begin{array}{c}\text { I want to know where I can get information } \\
\text { because I want to use it as a supplement. } \\
\text { Cannot say either/ } \\
\text { Do not think so }\end{array}$ & \multicolumn{1}{c}{ Total } \\
\hline \multirow{2}{*}{ Think so } & $\begin{array}{c}\text { Think so } \\
\text { Frequency }\end{array}$ & 126 & 44 & 170 \\
& $\%$ & 74.1 & 25.9 & 100.0 \\
\hline Cannot say either/ & $\begin{array}{c}\text { Frequency } \\
\text { Do not think so }\end{array}$ & 88 & 70 & 158 \\
\hline \multirow{2}{*}{ Total } & Frequency & 55.7 & 44.3 & 100.0 \\
& $\%$ & 214 & 114 & 328 \\
& & 65.2 & 34.8 & 100.0 \\
\hline
\end{tabular}




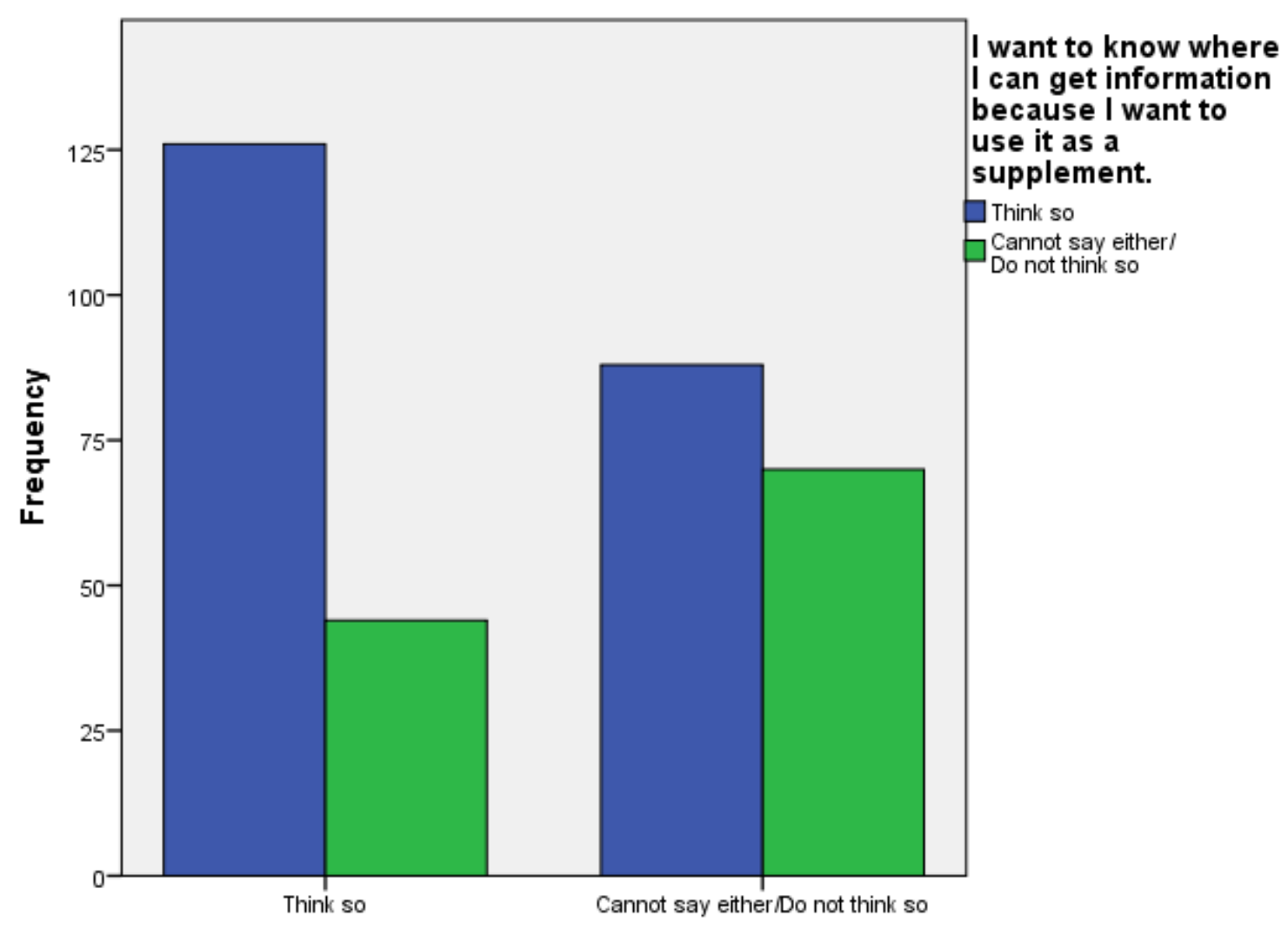

Are you careful for the health?

Figure 5. Summary for Null Hypothesis A-5)

The null hypothesis is rejected with $1 \%$ significance level. It can be said that those who want to know where he/she can get information because he/she wants to use it as a supplement are careful of his/her health.

Null Hypothesis A-6): There is not so much difference whether those who want to know where he/she can get information because he/she wants to use it as a supplement have interest in the designated health food or not.

Summary table concerning Null Hypothesis A-6) is exhibited in Table 6.

Table 6. Summary table for Null Hypothesis A-6)

\begin{tabular}{|c|c|c|c|c|}
\hline \multirow[t]{2}{*}{$\begin{array}{l}\text { Do you take interest in the } \\
\text { designated health food? }\end{array}$} & \multicolumn{4}{|c|}{$\begin{array}{l}\text { I want to know where I can get information } \\
\text { because I want to use it as a supplement. } \\
\text { Cannot say either/ }\end{array}$} \\
\hline & & Think so & Do not think so & Total \\
\hline Think so & Frequency & 117 & 37 & 154 \\
\hline I hink so & $\%$ & 76.0 & 24.0 & 100.0 \\
\hline Cannot say either/ & Frequency & 97 & 77 & 174 \\
\hline Do not think so & $\%$ & 55.7 & 44.3 & 100.0 \\
\hline \multirow{2}{*}{ Total } & Frequency & 214 & 114 & 328 \\
\hline & $\%$ & 65.2 & 34.8 & 100.0 \\
\hline
\end{tabular}




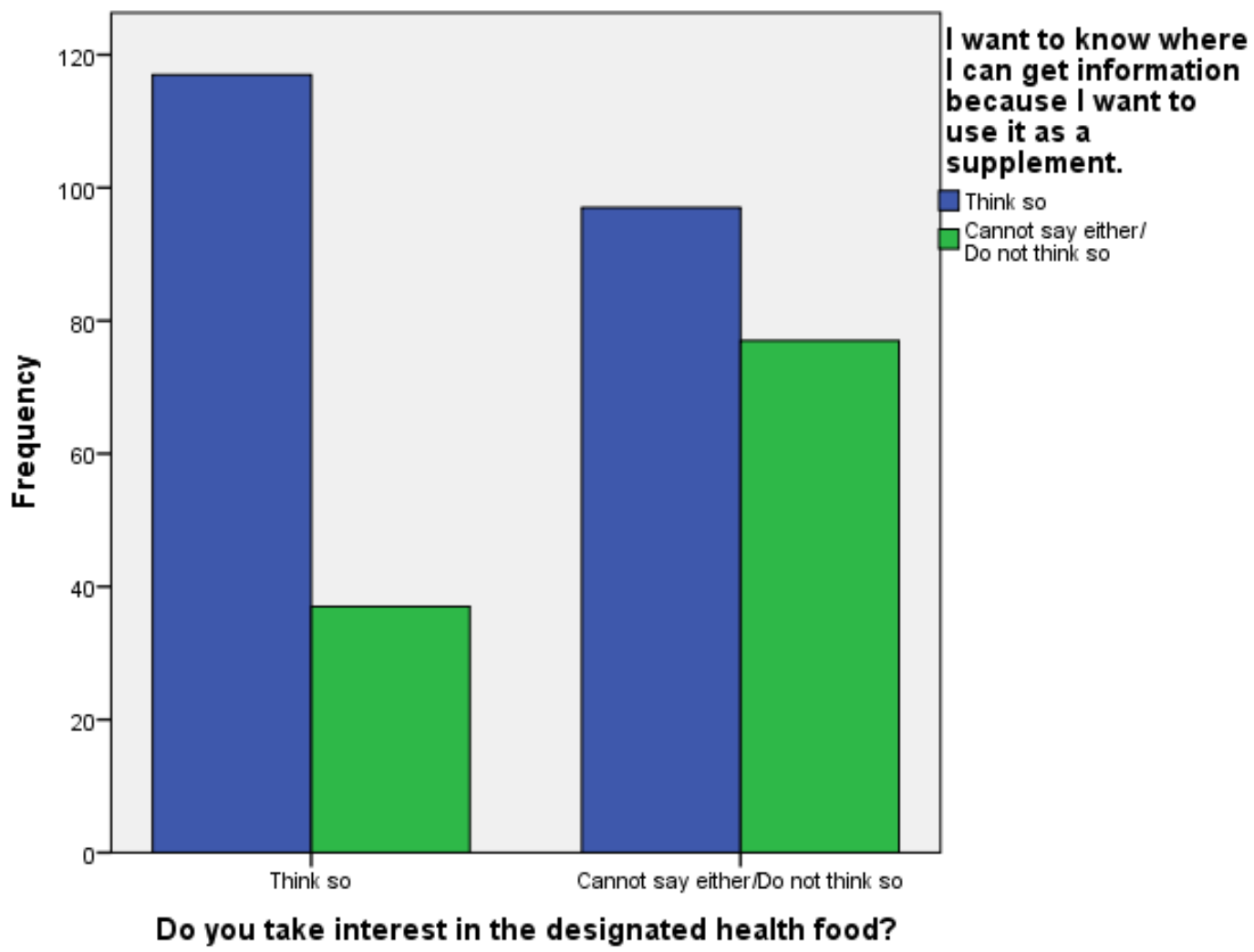

Figure 6. Summary for Null Hypothesis A-6)

The null hypothesis is rejected with $1 \%$ significance level. It can be said that those who want to know where he/she can get information because he/she wants to use it as a supplement have interest in the designated health food.

Null Hypothesis A-7): There is not so much difference whether those who want to know the hospital where the Rare Sugar is used as a tool for treatment have interest in a diet or not.

Summary table concerning Null Hypothesis A-7) is exhibited in Table 7.

Table 7. Summary table for Null Hypothesis A-7)

I want to know the hospital where the

Do you take interest in a diet?

Rare Sugar is used as a tool for treatment.
Cannot say either/ Do not think so Total

Think so

132

56.7

40

41.2

172

52.1

101
43.3

43.3

57

58.8

158

47.9

233

Total $\%$

significance probability 0.011 


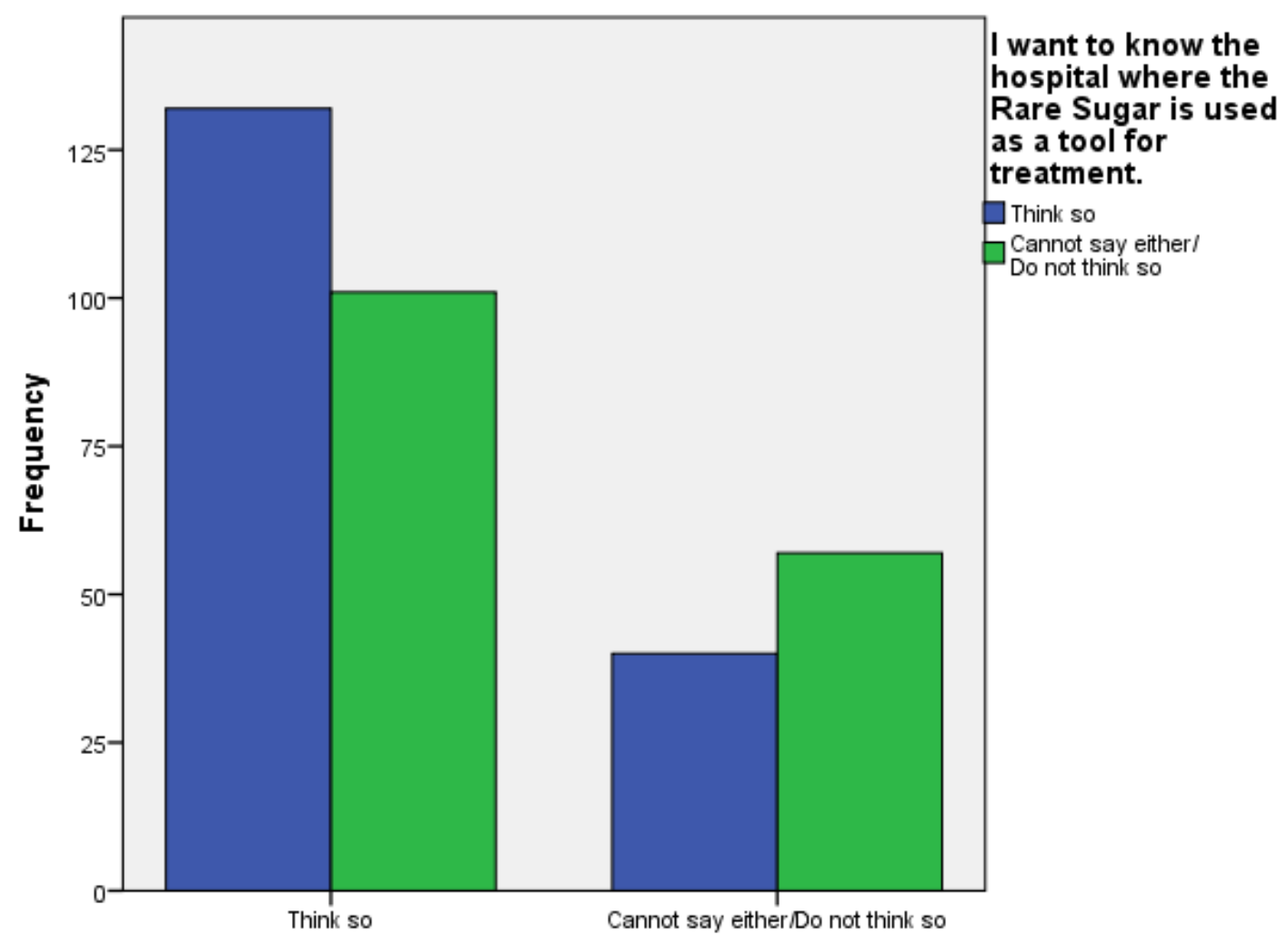

Do you take interest in a diet?

Figure 7. Summary for Null Hypothesis A-7)

The null hypothesis is rejected with 5\% significance level. It can be said that those who want to know the hospital where the Rare Sugar is used as a tool for treatment have interest in a diet.

Null Hypothesis A-8): There is not so much difference whether those who want to know the hospital where the Rare Sugar is used as a tool for treatment are careful of his/her health or not.

Summary table concerning Null Hypothesis A-8) is exhibited in Table 8.

Table 8. Summary table for Null Hypothesis A-8)

\begin{tabular}{ccrrr}
\hline $\begin{array}{c}\text { Are you careful for } \\
\text { the health? }\end{array}$ & & $\begin{array}{c}\text { I want to know the hospital where the } \\
\text { Rare Sugar is used as a tool for treatment. } \\
\text { Cannot say either/ } \\
\text { Do not think so }\end{array}$ & Total \\
\hline \multirow{2}{*}{ Think so } & $\begin{array}{c}\text { Frequency } \\
\text { Think so }\end{array}$ & 101 & 69 & 170 \\
& $\%$ & 59.4 & 40.6 & 100.0 \\
\hline Cannot say either/ & $\begin{array}{c}\text { Frequency } \\
\text { Do not think so }\end{array}$ & 70 & 89 & 159 \\
\hline Total & Frequency & 44.0 & 56.0 & 100.0 \\
& $\%$ & 171 & 158 & 329 \\
& & 52.0 & 48.0 & 100.0 \\
\hline & & & significance probability & 0.005
\end{tabular}




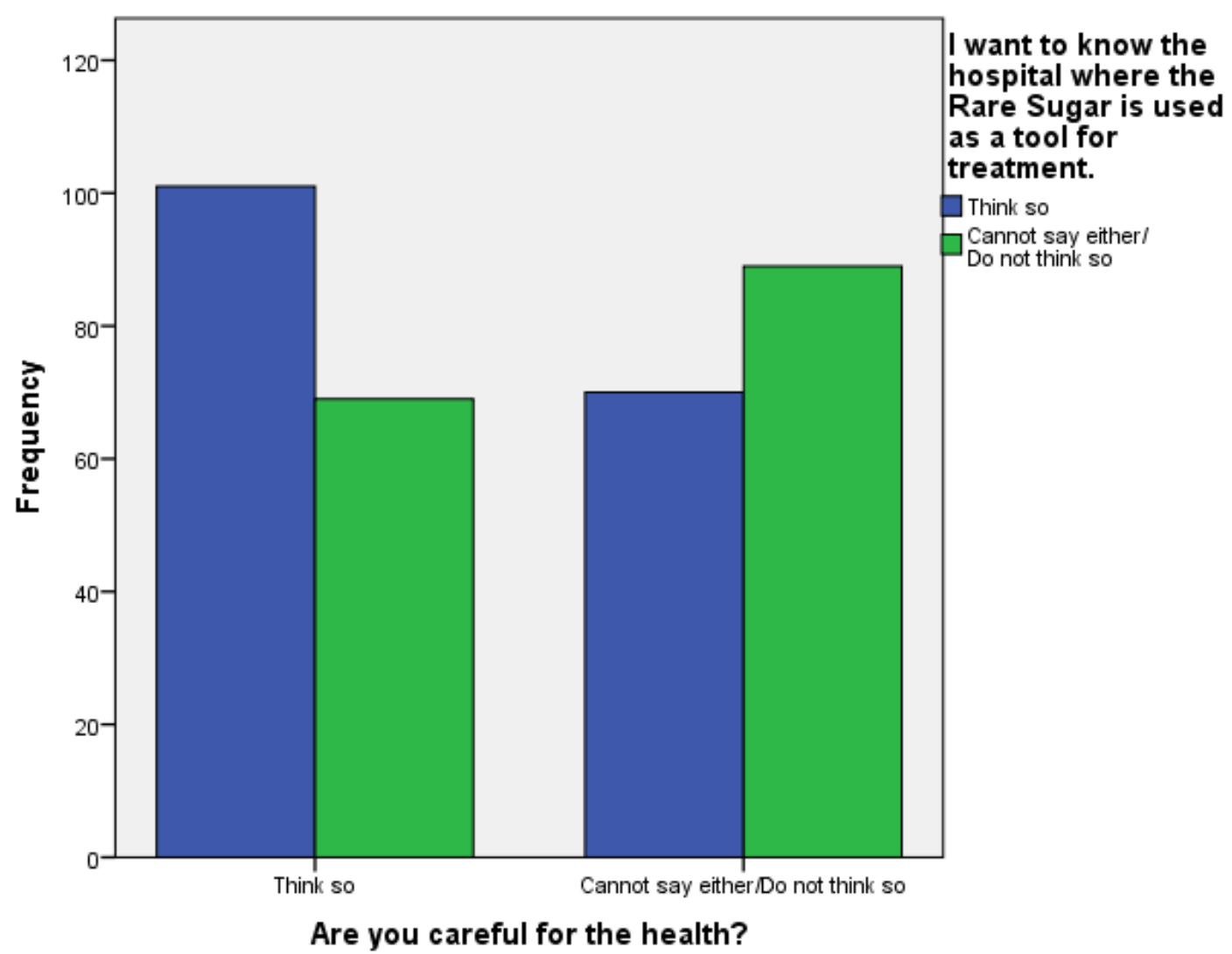

Figure 8. Summary for Null Hypothesis A-8)

The null hypothesis is rejected with $1 \%$ significance level. It can be said that those who want to know the hospital where the Rare Sugar is used as a tool for treatment are careful of his/her health.

Null Hypothesis A-9): There is not so much difference whether those who want to know the hospital where the Rare Sugar is used as a tool for treatment have interest in the designated health food or not.

Summary table concerning Null Hypothesis A-9) is exhibited in Table 9.

Table 9. Summary table for Null Hypothesis A-9)

\begin{tabular}{|c|c|c|c|c|}
\hline \multirow[t]{2}{*}{$\begin{array}{l}\text { Do you take interest in the } \\
\text { designated health food? }\end{array}$} & \multicolumn{4}{|c|}{$\begin{array}{l}\text { I want to know the hospital where the } \\
\text { Rare Sugar is used as a tool for treatment. } \\
\text { Cannot say either/ }\end{array}$} \\
\hline & & Think so & Do not think so & Total \\
\hline \multirow{2}{*}{ Think so } & Frequency & 92 & 63 & 155 \\
\hline & $\%$ & 59.4 & 40.6 & 100.0 \\
\hline \multirow{2}{*}{$\begin{array}{l}\text { Cannot say either/ } \\
\text { Do not think so }\end{array}$} & Frequency & 80 & 94 & 174 \\
\hline & $\%$ & 46.0 & 54.0 & 100.0 \\
\hline \multirow{2}{*}{ Total } & Frequency & 172 & 157 & 329 \\
\hline & $\%$ & 52.3 & 47.7 & 100.0 \\
\hline
\end{tabular}




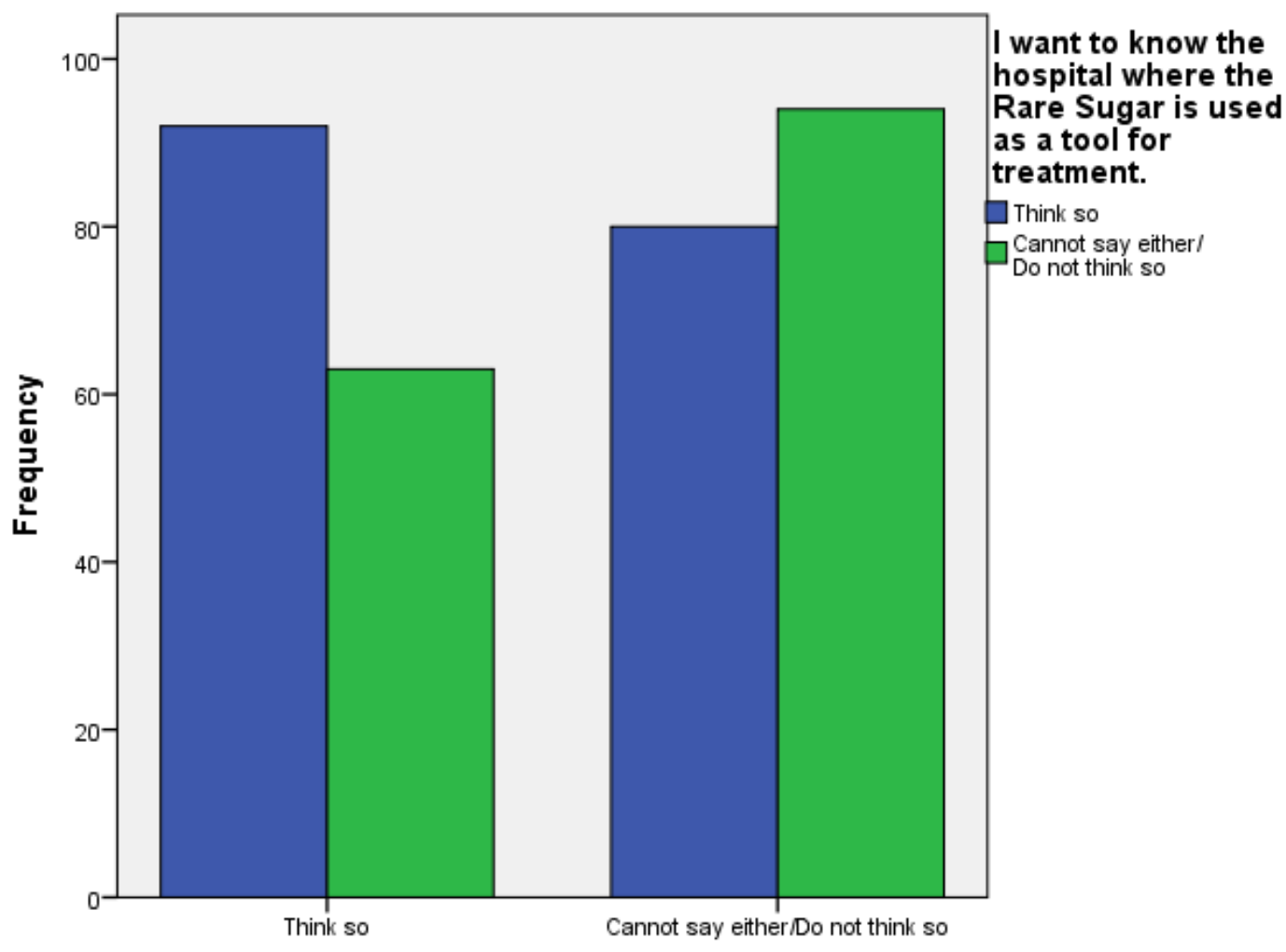

Do you take interest in the designated health food?

Figure 9. Summary for Null Hypothesis A-9)

The null hypothesis is rejected with 5\% significance level. It can be said that those who want to know the hospital where the Rare Sugar is used as a tool for treatment have interest in the designated health food.

\section{Remarks}

The results for Hypothesis Testing are as follows. 8 cases out of 9 are rejected (A-1, A-2, A-4, A-5, A-6, A-7, A-8, A-9). It can be said that the majority of issues are insisted clearly.

\section{Conclusion}

The Rare Sugars exist naturally and have many kinds (more than 50). They have good effect for health such as prevention of increasing the blood-sugar level after eating, suppression of fat accumulation, suppression of increasing the blood pressure, and anti-oxidative effect etc. It is in the spotlight for many people especially for those who are in the metabolic syndrome. The Rare Sugars are prevailing now in Japan. It is utilized in cooking, drinks and cakes etc. The big food companies are putting it into their products and make promotions by TV and other media. There are few related papers concerning the marketing research and its utilization of this matter. In this paper, a questionnaire investigation was executed to the student of Kagawa Junior College in order to clarify consumers' current condition and their consciousness, and to seek the possibility of utilizing the Rare Sugars. Hypothesis Testing analysis was conducted based on that. We have set nine issues as follows.

A-1) Those who want to know where he/she can buy it because he/she wants to use it as a seasoning have interest in a diet.

A-2) Those who want to know where he/she can buy it because he/she wants to use it as a seasoning are careful of his/her health.

A-3) Those who want to know where he/she can buy it because he/she wants to use it as a seasoning have interest in the designated health food. 
A-4) Those who want to know where he/she can get information because he/she wants to use it as a supplement have interest in a diet.

A-5) Those who want to know where he/she can get information because he/she wants to use it as a supplement are careful of his/her health.

A-6) Those who want to know where he/she can get information because he/she wants to use it as a supplement have interest in the designated health food.

A-7) Those who want to know the hospital where the Rare Sugar is used as a tool for treatment have interest in a diet.

A-8) Those who want to know the hospital where the Rare Sugar is used as a tool for treatment are careful of his/her health.

A-9) Those who want to know the hospital where the Rare Sugar is used as a tool for treatment have interest in the designated health food.

The results for Hypothesis Testing analysis are as follows. 8 cases out of 9 are rejected (A-1, A-2, A-4, A-5, A-6, A-7, A-8, A-9). It can be said that the majority of issues are insisted clearly.

Further study on this should be executed such as multivariate analysis. Various cases should be investigated here after.

\section{Acknowledgements}

The authors are grateful to all those who supported us for answering the questionnaire investigation.

\section{References}

Hayashi, N., Iida, T., Yamada, T., Okuma, K., Takehara, I., Yamamoto, T., ... Tokuda, M. (2010). Study on the postprandial blood glucose suppression effect of D-psicose in borderline diabetes and the safety of long-term ingestion by normal human subjects. Biosci Biotechnol Biochem. 74(3),510-9. https://doi.org/10.1271/bbb.90707

Hirata, Y., Saito, M., Tsukamoto, I., Yamaguchi, F., Sui, L., Kamitori, K., ... Tokuda, M. (2009, May). Analysis of the inhibitory mechanism of D-allose on MOLT-4F leukemia cell proliferation. J. Biosci Bioeng., 107(5), 562-8. https://doi.org/10.1016/j.jbiosc.2008.12.021

Hossain, M.A., Kitagaki, S., Nakano, D., Nishiyama, A., Funamoto, Y., Matsunaga, T., .. Tokuda, M. (2011, Feb. 4). Rare sugar D-psicose improves insulin sensitivity and glucose tolerance in type 2 diabetes Otsuka Long-Evans Tokushima Fatty (OLETF) rats. Biochem Biophys Res Commun, 405(1), 7-12. https://doi.org/10.1016/j.bbrc.2010.12.091

Iida, T., Hayashi, N., Yamada, T., Yoshikawa, Y., Miyazato, S., Kishimoto, Y., ... Izumori K. (2010). Failure of d-psicose absorbed in the small intestine to metabolize into energy and its low large intestinal fermentability in humans. Metabolism, 59(2), 206-14. https://doi.org/10.1016/j.metabol.2009.07.018

Kajikawa, T., Tada, S., Kitanaka, A., Tokuda, M., Taminat, T., \& Analy, J. (2010). Reactivity of rare sugar D-allose during glycation of human serum albumin. Bio-Sci., 33(3), 227-236.

Yamada, K., Noguchi, C., Kamitori, K., Dong, Y., Hirata, Y., Hossain, M.A., ... Yamaguchi, F. (2012, Feb.). Rare sugar d-allose strongly induces thioredoxin-interacting protein and inhibits osteoclast differentiation in Raw264 cells. Nutr Res, 32(2), 116-23. https://doi.org/10.1016/j.nutres.2011.12.010 
Appendix. Questionnaire about the Rare Sugars

$\$$ Questionnaire about the Rare Sugars

The Rare Sugars exist naturally and have many kinds (morethan 50). They have good effect for health such as prevention of increasing the a blood-sugar level after eating, suppression of fat accumulation, suppression of increasing the blood pressure, and antioxidative effect etc. It is in the spotlight for many people especially for those who are in the metabolic syndrome.

Please select the appropriate item in each column.(Plural answers are allowed for Q2, 9, 24, 28. Select (1) (5) in the right colum for Q7, 8, 10-23, 25-27.)

1.We ask you about the Rare Sugars.

1-1. Do you know the Rare Sugars?

Q1 (1)Know (2)Do not know ( $\Rightarrow$ Proceed to Q8 who has selected (2) and answer until to the last.)

1-2. We ask you who have selected (1). Where did you know the Rare Sugar?【Plural answers are allowed】

Q2 (1)TV (2)Magazine (3)Newspaper (4)Shop (5)Vending Machine (6)Seminar (7)Internet (8)Hear from another person (9)Miscellaneous ( )

1-3. Do you know that the Rare Sugar has effect on obese prevention and/or diabetes prevention etc.?

Q3 (1)Know (2)Do not know

1-4. Have you heard or used the syrup which includes Rare Sugar "Rare Sugar Sweet"?

Q4 (1)Heard (2)Not heard

Q5 (1)Used (2)Not used

1-5. Have you drunk or eaten the food which includes the Rare Sugar?

Q6 (1) Yes (2) No

Q7 1-6. We ask you who have selected (1) in Q6.Was the Rare Sugar effective after using it for more than one month? ( $\Rightarrow$ Proceed to Q9)

Q8 1-7. We ask you who have sete

the Rare Sugar is included?

1-8. What kind of food do you want to eat if the Rare Sugar is included?【Plural answers are allowed】

Q9 (1)Cake (2)Juice (3)Japanese food (4)Western food (5)Chinese food (6)Miscellaneous ( 1-9.How do you want to use the Rare Sugar?

Q10 a. I want to use it in the cooking.

\begin{tabular}{|l|l} 
Q11 & b. I can easily use it if there is a recipe. \\
\hline Q12 & c. I
\end{tabular}

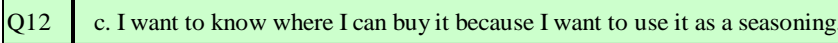

Q13 d. I want to know where I can get information because I want to use it as a supplement.

Q14 e. I want to know the hospital where the Rare Sugar is used as a tool for treatment.

Q15 f. I want to know how long I should use it in order to confirm the effectiveness.

1-10.Do you have a question(doubt) or anxiety for the Rare Sugar?

Q16 a. It is not so popular.

Q17 b. It seems to be expensive.

Q18 c. I cannot grasp the concrete effect.

Q19 d. I cannot have confidence that it is safe for anybody.

Q20 $\quad$ e. Surrounding people do not use it so often.

Q21 f. I cannot find the food in the shop in which the Rare Sugar is included.

Q22 g. I cannot guess how I should use the Rare Sugar to what kind of cooking?

Q23 h. Miscellaneous(

1-11.Choose the drink that you are interested in.[Plural answers are allowed)

Q24 1 (1)ajiru (2)OS-1(oral rehydration solutionDrink for sports) (4)designated health drink (5)drink with the Rare Sugar (6)None (7)Miscellaneous (

Q25 1-12. Do you take interest in a diet?

Q26 1-13. Are you careful for the health?

Q27 1-14. Do you take interest in the designated health food?

1-15. Which method would be suitable for the Rare Sugar to become popular?

(1)TV CM (2)Use Twitter,Facebook (3)Advertisement by the company (4)Spread the way of cooking (5)Sell candy with the Rare Sugar

Q28 (6) Sell juice with the Rare Sugar (7)Restaurant at which the Rare Sugar is used in the cooking (8)Use it in the food at the hospital (9)Sell it as a supplement (10Make promotion by utilizing famous sportsmen or entertainers (11)Miscellaneous (

2.What is your hobby? (Select only one in the right hand column)

Q29 2-1.Playing Sports: (1)Baseball (2)Football (3)Tennis (4)Golf (5)Miscellaneous (

Q30 2-2. Watching Sports: (1)Baseball (2)Football (3)Tennis (4)Golf (5)Miscellaneous ( )

Q31 2-3. Drinking: (1)Beer (2)Wine (3)Japanese wine-sake (4)Japanese liquor-shochu (5)Whisky

Q31 6) Miscellaneous ( )

\begin{tabular}{||l|l|l|l|l|}
\hline $\begin{array}{l}\text { (1) Like it } \\
\text { very much }\end{array}$ & $\begin{array}{l}\text { 2)Slightly } \\
\text { like it }\end{array}$ & $\begin{array}{l}\text { (3) Ordinary } \\
\text { level }\end{array}$ & & \\
\begin{tabular}{|l} 
(1) Like it \\
very much
\end{tabular} & $\begin{array}{l}\text { 2) Slightly } \\
\text { like it }\end{array}$ & $\begin{array}{l}\text { (3) Ordinary } \\
\text { level }\end{array}$ & & \\
\begin{tabular}{|l} 
(1) Like it \\
very much
\end{tabular} & $\begin{array}{l}\text { (2) Slightly } \\
\text { like it }\end{array}$ & $\begin{array}{l}\text { (3)Ordinary } \\
\text { level }\end{array}$ & & \\
\hline
\end{tabular}


3. We ask you questions about your current condition.

Q32 3-1. Sex: (1)Male (2)Female

Q33 3-2. Age: (1) 19 (2) $20 \sim 29$ (3) $30 \sim 39$ (4) $40 \sim 49$ (5) $50 \sim 59$ (6) More than 60

Q34 3-3. Occupation: (1)Student (2)Officer (3)Company Employee (4)Clerk of Organization (5)Independents (6)Part-timer (7)Housewife (8)Miscellaneous(

Q35 3-4. Address: (1)Prefecture( ) (2)City(

Q36 3-5. What kind of lifestyle do you like?: (1)Outdoor (2)Indoor (3)Not either 